\title{
Factors associated with the needs of specialised dental treatment among adults aged 35-44 years old in the state of Minas Gerais, Brazil: a multilevel cross-sectional study
}

\author{
Fatores associados às necessidades de tratamento odontológico \\ entre adultos com idade entre 35 e 44 anos na atenção secundária \\ no estado de Minas Gerais, Brasil: estudo transversal multinível
}

Mônica Baltazar de Azevedo (https://orcid.org/0000-0001-7476-1919) ${ }^{1}$

Rafaela da Silveira Pinto (https://orcid.org/0000-0002-6169-7708) ${ }^{1}$

Mauro Henrique Nogueira Guimarães de Abreu (https://orcid.org/0000-0001-8794-5725) ${ }^{1}$

Simone Dutra Lucas (https://orcid.org/0000-0001-7875-4492) ${ }^{1}$

${ }^{1}$ Departamento de Odontologia Social e Preventiva, Faculdade de Odontologia, Universidade Federal de Minas Gerais. Av. Presidente Antônio Carlos 6627, Pampulha. 31270-901 Belo Horizonte MG Brasil. web_monica@yahoo.com.br

\begin{abstract}
This study evaluated the individual and contextual factors associated with the specialised dental treatment needs of a population of adults aged 35 to 44 years old in the state of Minas Gerais. The individual variables were obtained from the database of the SB Minas Gerais project - a survey of oral health status of the population of Minas Gerais, Brazil. The variables at the municipal level were derived from any available public databases related to oral health services. A multilevel analysis was performed to evaluate the association of independent individuals and contextual variables with or without dental treatment needs in the secondary care of the oral health network. Individuals with a higher income (OR 0.53; CI95\% 0.31-0.93) and with greater access to oral health care (OR 0.94; CI95\% 0.90-0.99) had less secondary care treatment needs. Income and access to oral health care are related to the needs of specialised dental treatment in Minas Gerais. Key words Dental care, Primary Health Care, Dental Health Services, Health Services Accessibility, Social Determinants of Health
\end{abstract}

Resumo Esse estudo avaliou os fatores individuais e contextuais associados às necessidades de tratamento odontológico especializado na população de 35 a 44 anos no estado de Minas Gerais. Foram utilizados dados secundários referentes à saúde bucal de adultos, obtidos no levantamento epidemiológico da Pesquisa das Condições de Saúde Bucal da população mineira e de dados municipais, obtidos de bancos de dados públicos. Foi realizada análise multinível para avaliar a associação de variáveis independentes individuais e contextuais com ausência ou presença de necessidades de tratamento odontológico na atenção secundária da rede de saúde bucal. Os indivíduos com maior renda (OR 0,53; IC95\% 0,31-0,93) e com maior acesso aos cuidados em saúde bucal, que caracterizam a cobertura de primeira consulta da atenção primária (OR 0,94; IC95\% 0,90-0,99) apresentaram menor necessidade de tratamento odontológico na atenção secundária. A renda e o acesso aos cuidados em saúde bucal estão relacionados às necessidades de tratamento odontológico especializado em Minas Gerais.

Palavras-chave Assistência odontológica, Atenção Primária à Saúde, Serviços de Saúde Bucal, Acesso aos Serviços de Saúde, Determinantes Sociais da Saúde 


\section{Introduction}

Brazilian oral health care has been marked by low population coverage for a long time, evidencing an excluding model. In 1998, about 29.6 million Brazilians (19\%) had never been to the dentist ${ }^{1}$. In order to change this reality, the Oral Health Teams (OHT) were included in the Family Health Program in 2000, providing greater access to oral health services ${ }^{2,3}$.

In 2004, the National Oral Health Policy (NOHP), known as Brasil Sorridente ("Smiling Brazil") was launched ${ }^{4}$. This policy was based on a national epidemiological survey conducted in 2003, called "SBBrasil 2003 - Oral Health Conditions of the Brazilian Population". The NOHP took into consideration: oral health promotion, prevention, diagnosis, treatment, rehabilitation actions, strengthening the concept of health surveillance, primary care, ensuring the hegemonic universal access and integral principles of the Unified Health System (SUS, in Portuguese).

The increased transfer of federal, state, and municipal resources provided greater regional independence and co-participation in oral health, resulting from the inclusion of OHT in the Family Health Strategy. Specialized dental care (SDC) was reorganised through the creation of the Dental Specialties Centres. This implementation facilitated continuity of dental treatment through specialised and more complex procedures, using a referral and counter-referral system ${ }^{2,3}$.

However, even with the adoption of the NOHP, other factors still interfere with the oral health conditions of Brazilian adults, this is a consequence of previous years under the exclusionary and surgical model. The existence of dental treatment needs among adults is partly a consequence of the failure or lack of oral health care and of people's difficulty in obtaining an adequate, accessible, comprehensive, and sufficient dental service. These needs are unequally distributed among people. They are also affected by the determinants of dental caries and are strongly associated with factors at an individual level such as: income, education, gender, ethnicity and the use of dental services and a contextual level such as the Human Development Index ${ }^{5-7}$.

In Minas Gerais, the state with the second largest population in Brazil and suffering with a social inequality setting similar to the rest of the country. The State Health Secretariat (SESMG), in 2012, carried out the epidemiological homebased survey "SB Minas Gerais - Oral Health Conditions of the population of Minas Gerais", which was state-wide and provided a representative sample for the state. SB Minas Gerais (SBMG2012) identified the main dental treatment needs. Therefore, it is important that, for the first time in the state, they are associated with their individual and contextual determinants for a better understanding of the causes of oral health inequities ${ }^{8}$.

Knowledge about adult oral health and its determinants is important because few national studies prioritise the risk factors of the individual and contextual level at the same time. This age group historically demands a high volume of oral health care. Some studies linking social determinants to oral health problems are available, but few use a multi-level analysis relating individual and contextual factors with an emphasis on dental treatment needs $s^{5,69-16}$. The identification of dental treatment needs in this population in secondary care is the first stage for the development and planning of public health programs. Therefore, this paper aims to identify the association between individual factors, contextual factors and specialised dental treatment needs in the population aged 35-44 years in the state of Minas Gerais.

\section{Methods}

This is a multi-level, cross-sectional, analytical population-based study using secondary data on adult oral health obtained from the SBMG2012 and municipal data obtained from public databases.

\section{Study setting/location}

The survey was conducted in the municipalities of the state of Minas Gerais. Minas Gerais is the state with the fourth largest territorial area and the second in terms of the number of inhabitants, with a population estimated to be around 21 million inhabitants in 2017. Located in the south-eastern macro-region, it has the third largest Gross Domestic Product of the country ${ }^{17}$.

\section{Population and sample}

The SBMG2012 evaluated a sample of individuals in the 35-44 years old age group. This sample was calculated and selected by stratified sampling techniques in a cluster of 1,207 adults, of which 25 refused to have an oral examination (loss $=2.1 \%)$. For the state capital, they used sec- 
ondary data from the national study SB Brazil $2010^{18}$. The prevalence of caries and the mean number of decayed, missing and filled teeth (DMFT) were used as a reference to calculate the sample size associated with a specific error. A variance of 53.7, an estimated error of $5 \%$, a design effect of 2 and a non-response rate of $20 \%$ was used as a parameter to calculate the sample for the inland domains.

They excluded non-urban census tracts, invalid sectors (lack of information or invalid codes), sectors in which there were no residents in all age groups and sectors with less than 50 households. This study only considered those individuals in the age group 35-44, living in the municipalities selected for the Minas Gerais sample and who agreed to participate in the research.

\section{Data collection}

Individual data were identified in the SBMG2012. In this study, dental caries, periodontal disease, and dental prosthesis needs were measured by previously calibrated examiners (kappa > 0.65). All the collection data was recorded on a Personal Digital Assistant (PDA) device, which generated a database, removing the need for later typing.

The contextual-level independent variables were searched in the public government databases such as the Department of Informatics of the Unified Health System (DATASUS), the Primary Care Department of the Ministry of Health (DAB/MS), the State Health Secretariat of Minas Gerais (SESMG) and the João Pinheiro Foundation (FJP).

\section{Dependent variable}

The dependent variable was constructed based on the main adult dental treatment needs related to dental caries, periodontal disease, and the need for a dental prosthesis. These were divided according to the service in which they were performed - Primary Health Care (PHC) and Specialised Dental Care (SDC).

The needs related to the treatment of dental caries in the PHC included restoration of one, two or more surfaces, crowns and aesthetic facets, as well as extractions and sealants. Endodontic needs were considered under special care. The need for a dental prosthesis was included in the PHC because the Brazilian health service offers clinical procedures for dental prostheses at this level of care ${ }^{19}$.
For periodontal disease, the treatment of gingival bleeding, dental calculus and shallow periodontal pockets (under $5 \mathrm{~mm}$ ) were included in PHC. Deep pockets (more than $5 \mathrm{~mm}$ ) required treatment in SDC.

Individuals with no dental care need or those with no specialised dental care needs were classified as "Does not require or only requires PHC". Those who have any specialised dental care needs, with or without any primary dental care needs, were categorised as "Requires $\mathrm{PHC}+$ specialised care or only specialised care”.

\section{Independent variables}

At the individual level (Level 1) the variables of gender, household income, education, number of residents at home, ethnicity/skin colour, time elapsed since the patient's last dentist appointment, type of service used and the main reason for a dental appointment were used. Level 2 contextual-level variables included allocation factor, access to individual dental care, frequency of OHT with an Oral Health Technician (TSB), mean supervised dental brushing, frequency of dental extraction, emergency dental care attendance, prosthesis laboratory availability and SDC availability in the municipality (Table 1).

\section{Statistical Analysis}

The statistical analyses were performed using the Statistical Package for Social Sciences (SPSS for Windows, version 25.0, SPSS Inc., Chicago, IL, USA) and the Hierarchical Linear and Nonlinear Modelling framework (HLM 6.08) ${ }^{20}$.

The dependent variable was the need for dental treatment in secondary care. Data were hierarchically structured at two levels: individual variables (Level 1) nested within municipal variables (Level 2).

A multilevel analysis was used to evaluate the association between municipal and individual variables with a lack or presence of dental treatment needs. The multilevel structure of the analyses included 1,175 individual variables (Level 1) from 57 municipalities (Level 2), this was obtained through nonlinear logit link function analyses using the fixed effects/random intercept scheme. The parameters were estimated using the predictive quasi-likelihood (PQL) of the restricted maximum likelihood method. A multilevel logistic regression model was constructed. In the first step, a "null model" estimated the basic partitioning of data variability between the 
Table 1. Study dependent and independent variables.

\begin{tabular}{|c|c|c|c|}
\hline Variable & Description & Categorization & Source \\
\hline \multicolumn{4}{|c|}{ Dependent Variable } \\
\hline $\begin{array}{l}\text { Dental treatment } \\
\text { needs }\end{array}$ & $\begin{array}{l}\text { Consisting of caries treatment, } \\
\text { periodontal disease and prosthesis needs. }\end{array}$ & $\begin{array}{l}\text { Does not require or only } \\
\text { requires PHC } \\
\text { Requires PHC + specialized care } \\
\text { or only specialized care }\end{array}$ & SBMG2012 \\
\hline \multicolumn{4}{|c|}{ Independent Variables } \\
\hline \multicolumn{4}{|c|}{ Individual level } \\
\hline Gender & Self-reported gender & $\begin{array}{l}\text { Female } \\
\text { Male }\end{array}$ & SBMG2012 \\
\hline $\begin{array}{l}\text { Household } \\
\text { income }\end{array}$ & $\begin{array}{l}\text { Total income received by all family } \\
\text { members in the month preceding the } \\
\text { survey, in Brazilian reais }(R \$) \text {. R } \$ 1.00= \\
\mathrm{U} \$ 0.50 \text { dollars in } 29 / 06 / 2012\end{array}$ & $\begin{array}{l}\text { Under } \mathrm{R} \$ 1,500.00 \\
\text { Above } \mathrm{R} \$ 1,500.00\end{array}$ & SBMG2012 \\
\hline Schooling & $\begin{array}{l}\text { Years of formal education. The variable } \\
\text { was expressed as mean of years of study. }\end{array}$ & Continuous variable & SBMG2012 \\
\hline $\begin{array}{l}\text { Numbers of } \\
\text { residents at home }\end{array}$ & Number of people residing at home. & Continuous variable & SBMG2012 \\
\hline $\begin{array}{l}\text { Ethnicity/skin } \\
\text { color }\end{array}$ & Self-reported skin color. & $\begin{array}{l}\text { White } \\
\text { Non-white }\end{array}$ & SBMG2012 \\
\hline $\begin{array}{l}\text { Time elapsed } \\
\text { since the patient's } \\
\text { last dentist } \\
\text { appointment }\end{array}$ & $\begin{array}{l}\text { Refers to the frequency of use of dental } \\
\text { services, i.e. if individuals had never used } \\
\text { a dental service, used it in the last year or } \\
\text { less frequently than in the last year. }\end{array}$ & $\begin{array}{l}\text { Never used } \\
\text { More than one year } \\
\text { Less than one year }\end{array}$ & SBMG2012 \\
\hline $\begin{array}{l}\text { Type of service } \\
\text { used }\end{array}$ & $\begin{array}{l}\text { Type of service used at the last dental } \\
\text { appointment. The non-public service } \\
\text { encompassed all private services such as } \\
\text { covenants, health plans and others. }\end{array}$ & $\begin{array}{l}\text { Never used } \\
\text { Public } \\
\text { Non-public }\end{array}$ & SBMG2012 \\
\hline $\begin{array}{l}\text { Main reason for } \\
\text { consultation }\end{array}$ & $\begin{array}{l}\text { Reason why the individual sought care at } \\
\text { the last dental appointment. }\end{array}$ & $\begin{array}{l}\text { Never used } \\
\text { Curative procedures } \\
\text { Check-up/preventive procedures }\end{array}$ & SBMG2012 \\
\hline
\end{tabular}

it continues

two levels before the inclusion of individual and the municipal characteristics needed to be taken into account.

Level 1 variables were initially incorporated one by one into the model before being tested together $(\mathrm{p}<0.25)$, this was followed by the test for municipal variables (Level 2), which were incorporated one by one, with the calculation of $\mathrm{p}$-values (Student's t-test). The final multilevel analysis model was constructed with all the individual variables achieving $\mathrm{p}<0.25$. Odds Ratio $(\mathrm{OR})$ and their respective $95 \%$ confidence intervals (CI95\%) were estimated for each analysis. The reliability estimate was used to determine the goodness-of-fit of the final multilevel model. Final models included only variables with p-value $<0.05$.

\section{Ethical aspects}

The Research Ethics Committee of PUC Minas approved the epidemiological survey SBMG2012.

\section{Results}

Level 1 variables are described in Table 2. The mean number of years of education was $8.76( \pm$ 4.04) and the mean number of residents in the household was $4.05( \pm 1.55)$.

Level 2 quantitative variables are shown in Table 3. Among the 57 municipalities evaluated, $26(45.6 \%)$ had the resources available for prosthesis production. SDC was in place in 24 municipalities (42.1\%).

The results of the null model indicate that the treatment needs in secondary care were different 
Table 1. Study dependent and independent variables.

\begin{tabular}{|c|c|c|c|}
\hline Variable & Description & Categorization & Source \\
\hline \multicolumn{4}{|c|}{ Independent Variables } \\
\hline \multicolumn{4}{|c|}{ Contextual level } \\
\hline Allocation factor & $\begin{array}{l}\text { Calculated based on the index of health } \\
\text { needs and economic size. It measures } \\
\text { the municipal relative need of financial } \\
\text { resources so that the municipality bears } \\
\text { with its own resources the necessary } \\
\text { health treatments for its population. }\end{array}$ & Continuous variable & FJP \\
\hline $\begin{array}{l}\text { Access to } \\
\text { individual dental } \\
\text { care }\end{array}$ & $\begin{array}{l}\text { Proportion of people who received a } \\
\text { first dental appointment programmed } \\
\text { in the SUS to diagnose and elaborate a } \\
\text { preventive / therapeutic plan to meet } \\
\text { the detected needs. Calculated as a } \\
\text { percentage of population. }\end{array}$ & Continuous variable & DATASUS \\
\hline $\begin{array}{l}\text { Frequency of } \\
\text { Oral Health Team } \\
\text { (OHT) with } \\
\text { an Oral Health } \\
\text { Technician (TSB) }\end{array}$ & $\begin{array}{l}\text { Number of OHT with TSB in relation } \\
\text { to the total of oral health teams of the } \\
\text { Family Health Strategy. }\end{array}$ & Continuous variable & $\mathrm{DAB} / \mathrm{MS}$ \\
\hline $\begin{array}{l}\text { Mean supervised } \\
\text { dental brushing }\end{array}$ & $\begin{array}{l}\text { Number of supervised individual dental } \\
\text { brushing performed divided by the } \\
\text { population. This total is divided by the } 12 \\
\text { months of the year. It measures access to } \\
\text { preventive procedures. }\end{array}$ & Continuous variable & DATASUS \\
\hline $\begin{array}{l}\text { Dental extraction } \\
\text { frequency }\end{array}$ & $\begin{array}{l}\text { Proportion of permanent tooth } \\
\text { extraction compared to other primary } \\
\text { care dental clinical. } \\
\text { It measures the quality of service with } \\
\text { regard to whether or not it is a mutilating } \\
\text { service. }\end{array}$ & Continuous variable & DATASUS \\
\hline $\begin{array}{l}\text { Emergency dental } \\
\text { care frequency }\end{array}$ & $\begin{array}{l}\text { Average number of urgent care per } 100 \\
\text { inhabitants in Minas Gerais in the year } \\
2012 .\end{array}$ & Continuous variable & DATASUS \\
\hline $\begin{array}{l}\text { Prosthesis } \\
\text { laboratory } \\
\text { availability }\end{array}$ & $\begin{array}{l}\text { Characterizes whether the municipality } \\
\text { has a dental prosthesis laboratory. }\end{array}$ & $\begin{array}{l}\text { No } \\
\text { Yes }\end{array}$ & SESMG \\
\hline SDC Availability & $\begin{array}{l}\text { Characterizes whether the municipality } \\
\text { has a dental specialties center (specialized } \\
\text { oral health care). }\end{array}$ & $\begin{array}{l}\text { No } \\
\text { Yes }\end{array}$ & SESMG \\
\hline
\end{tabular}

among the municipalities surveyed, justifying the need for a multilevel analysis (Variance component $=0.63258, \mathrm{DF}=56, \mathrm{p}<0.001)$.

Table 4 shows the results of the non-adjusted analyses. At the individual level, income and years of education showed a statistically significant association with the need for secondary care treatment. While at the municipal level, only the variable access to individual dental care had a significant association.
As shown in Table 5, when considering the individual and contextual variables included in the multilevel analysis, individuals with a higher income - Level 1 (OR 0.53, 95\%CI 0.31-0.93) - and with a greater access to oral health care that characterised first-line PHC consultation coverage - Level 2 (OR 0.94; CI95\% 0.90-0.99) - showed a lower need for dental secondary care treatment. 


\section{Discussion}

This study has shown that greater access to oral health care, corresponding to the first dental consultation in Primary Health Care (PHC), and a higher income were the factors responsible for

Table 2. Descriptive data of adult sample characteristics Minas Gerais, Brazil, 2012.

\begin{tabular}{|c|c|c|}
\hline Variables $^{\star}$ & $\mathbf{n}$ & $\%$ (CI 95\%) \\
\hline \multicolumn{3}{|l|}{ Gender } \\
\hline Female & 776 & $65.10(61.47-68.57)$ \\
\hline Male & 431 & $34.89(31.42-38.52)$ \\
\hline \multicolumn{3}{|l|}{ Income } \\
\hline Under 1.500 Reais & 750 & $54.62(48.33-60.76)$ \\
\hline Above 1.500 Reais & 438 & $45.37(39.23-51.66)$ \\
\hline \multicolumn{3}{|l|}{ Ethnicity/skin color } \\
\hline White & 482 & $44.47(40.44-48.58)$ \\
\hline Non-white & 725 & $55.52(51.41-59.55)$ \\
\hline \multicolumn{3}{|c|}{$\begin{array}{l}\text { Time elapsed since the patient's last dentist } \\
\text { appointment }\end{array}$} \\
\hline Never used & 101 & $5.41(3.01-9.55)$ \\
\hline $\begin{array}{l}\text { More than one } \\
\text { year }\end{array}$ & 575 & $49.20(44.65-53.75)$ \\
\hline Less than one year & 526 & $45.38(41.01-49.83)$ \\
\hline \multicolumn{3}{|l|}{ Type of service used } \\
\hline Never used & 97 & $5.21(2.82-9.40)$ \\
\hline Public & 386 & $30.24(25.63-35.29)$ \\
\hline Non-public & 721 & $64.54(59.23-69.51)$ \\
\hline \multicolumn{3}{|l|}{ Reason for consultation } \\
\hline Never used & 97 & $5.20(2.89-9.38)$ \\
\hline $\begin{array}{l}\text { Curative } \\
\text { procedures }\end{array}$ & 876 & $73.97(69.18-78.26)$ \\
\hline $\begin{array}{l}\text { Check-up/ } \\
\text { preventive } \\
\text { procedures }\end{array}$ & 231 & $20.81(17.16-25.01)$ \\
\hline
\end{tabular}

* Frequencies calculated considering the sample weight. a lower need for dental treatment in secondary care.

Several studies have confirmed the influence of socioeconomic inequities on the use of health services ${ }^{21,22}$. Socioeconomic and demographic factors (race/colour, number of people in the household, family income, size of town) as well as basic treatment needs (number of teeth needing treatment) are associated with the use of public dental services ${ }^{23}$. As the people most in need of dental treatment generally have a lower income, they tend to seek a public health service instead of a private dental office, but this does not mean that they will have access to individual dental care. There are geographic and health services barriers (low oral health care coverage in primary and specialised dental care) that prevents a comprehensive care for the individual. The lack of access to the first dental appointment in oral health had the potential to postpone dental treatment, which increased the severity of the type of dental treatment needed in the next dental consultation. A previous study looking at the residents of more vulnerable areas in England (measured by National Statistics Socioeconomic Classification of occupation and highest educational attainment of household reference person) showed a greater need for restorative and surgical dental procedures due to a lack of access to preventative dental care $^{24}$.

The association between adult dental treatment needs and socioeconomic factors was identified in several other studies, ${ }^{6,25}$. This finding is consistent with studies that have evaluated the association between socioeconomic factors and oral health conditions ${ }^{26-28}$. Among the variables analysed, income was the most preponderant factor for the individual need for treatment. One of the most probable explanations for this is that financial problems are both hindering and demotivating factors in relation to seeking out den-

Table 3. Descriptive data of the contextual characteristics of the adult sample Minas Gerais, Brazil, 2012.

\begin{tabular}{lrrrr}
\hline \multicolumn{1}{c}{ Variables } & Mean & $\begin{array}{r}\text { Standard } \\
\text { Deviation }\end{array}$ & Minimum & Maximum \\
\hline Allocation factor & 1.41 & 0.20 & 1.08 & 1.80 \\
Access to individual dental care & 10.80 & 9.40 & 0.00 & 42.31 \\
Frequency of Oral Health Team (OHT) with an Oral & 25.61 & 35.79 & 0.00 & 100.00 \\
Health Technician (TSB) & & & & \\
Supervised dental brushing & 3.53 & 3.82 & 0.00 & 15.11 \\
Dental extraction frequency & 6.32 & 5.02 & 0.00 & 22.55 \\
Emergency dental care frequency & 2.47 & 3.05 & 0.00 & 13.53 \\
\hline
\end{tabular}


Table 4. Multilevel model for individual and contextual level variables associated with dental treatment needs in secondary care in adults $(\mathrm{n}=1,175)$, Minas Gerais, Brazil, 2012.

\begin{tabular}{|c|c|c|c|c|}
\hline Variables & $\begin{array}{l}\text { Odds } \\
\text { Ratio }\end{array}$ & $95 \% \mathrm{CI}$ & P-value & $\begin{array}{c}\text { Reliability } \\
\text { estimate }\end{array}$ \\
\hline \multicolumn{5}{|l|}{ Individual-level variables } \\
\hline \multicolumn{5}{|l|}{ Gender } \\
\hline Female & 1 & & & \\
\hline Male & 1.44 & $(0.88-2.35)$ & 0.145 & 0.504 \\
\hline \multicolumn{5}{|l|}{ Income } \\
\hline Under $\mathrm{R} \$ 1.500,00$ & 1 & & & \\
\hline Above $\mathrm{R} \$ 1.500,00$ & 0.53 & $(0.31-0.93)$ & 0.026 & 0.507 \\
\hline Years of schooling & 0.92 & $(0.87-0.98)$ & 0.011 & 0.509 \\
\hline Numbers of residents at home & 0.92 & $(0.78-1.07)$ & 0.268 & 0.502 \\
\hline \multicolumn{5}{|l|}{ Ethnicity/skin color } \\
\hline White & 1 & & & \\
\hline Non-white & 1.48 & $(0.90-2.44)$ & 0.123 & 0.504 \\
\hline \multicolumn{5}{|c|}{ Time elapsed since the patient's last dentist appointment } \\
\hline Never used & 1 & & & 0.505 \\
\hline More than 1 year & 0.87 & $(0.28-2.72)$ & 0.810 & \\
\hline Less than 1 year & 0.54 & $(0.19-1.53)$ & 0.243 & \\
\hline \multicolumn{5}{|l|}{ Type of service used } \\
\hline Never used & 1 & & & 0.506 \\
\hline Public & 1.20 & $(0.32-4.48)$ & 0.787 & \\
\hline Non-public & 0.69 & $(0.22-2.14)$ & 0.524 & \\
\hline \multicolumn{5}{|l|}{ Reason for last dental consultation } \\
\hline Never used & 1 & & & 0.511 \\
\hline Curative procedures & 0.98 & $(0.28-3.41)$ & 0.972 & \\
\hline Check-up/preventive procedures & 0.26 & $(0.07-0.98)$ & 0.046 & \\
\hline \multicolumn{5}{|l|}{ Municipal-level variables } \\
\hline Allocation factor & 0.29 & $(0.06-1.35)$ & 0.113 & 0.496 \\
\hline Access to individual dental care & 0.94 & $(0.90-0.99)$ & 0.010 & 0.459 \\
\hline $\begin{array}{l}\text { Frequency of oral health teams with oral health } \\
\text { technician }\end{array}$ & 1.00 & $(0.99-1.02)$ & 0.527 & 0.504 \\
\hline Monthly frequency of supervised dental brushing & 0.97 & $(0.89-1.06)$ & 0.450 & 0.503 \\
\hline Dental extraction frequency & 1.02 & $(0.94-1.11)$ & 0.598 & 0.503 \\
\hline Frequency of dental urgency & 1.03 & $(0.93-1.15)$ & 0.549 & 0.505 \\
\hline \multicolumn{5}{|l|}{ Dental prosthesis laboratory available } \\
\hline No & 1 & & & \\
\hline Yes & 1.33 & $(0.67-2.66)$ & 0.411 & 0.504 \\
\hline \multicolumn{5}{|l|}{ Dental specialties center available } \\
\hline No & 1 & & & \\
\hline Yes & 1.90 & $(0.92-2.95)$ & 0.083 & 0.484 \\
\hline
\end{tabular}

tal care, this increasing the need for such care. People on a low-income also evidenced further deterioration of the carious lesions and reported being predominant in their use of the public dental service ${ }^{7,9}$. These facts could lead to a demand for more dental secondary care treatment, this corroborates with the findings of other studies that showed the low-income profile of SDC us- $\mathrm{ers}^{29}$. So, public policies should tackle social inequalities in order to promote health ${ }^{11}$.

Thus, income was a predictive factor in individuals that would have at least one unmet dental treatment need and that this restrained demand could lead to a greater need for complex treatments, such as endodontics or subgingival scaling of deep pockets. Income was also found to 
Table 5. Final multilevel model for individual and contextual level variables associated with dental treatment needs in secondary care in adults $(\mathrm{n}=1,175)$, Minas Gerais, Brazil, 2012.

\begin{tabular}{|c|c|c|c|c|}
\hline Variables & $\begin{array}{l}\text { Odds } \\
\text { Ratio }\end{array}$ & $95 \% \mathrm{CI}$ & $\begin{array}{c}\text { P- } \\
\text { Value }\end{array}$ & $\begin{array}{c}\text { Reliability } \\
\text { estimate }\end{array}$ \\
\hline \multicolumn{4}{|c|}{ Individual-level variables } & 0.465 \\
\hline \multicolumn{5}{|l|}{ Income } \\
\hline $\begin{array}{l}\text { Under } \\
\mathrm{R} \$ 1,500.00\end{array}$ & 1 & & & \\
\hline $\begin{array}{l}\text { Above } \\
\mathrm{R} \$ 1,500.00\end{array}$ & 0.53 & $(0.31-0.93)$ & 0.026 & \\
\hline \multicolumn{5}{|c|}{ Municipal-level variables } \\
\hline $\begin{array}{l}\text { Access to } \\
\text { individual } \\
\text { dental care }\end{array}$ & 0.94 & $(0.90-0.99)$ & 0.011 & \\
\hline
\end{tabular}

influence access to dental care in Brazil, despite observing a decreased social disparity over time, which evidences an improvement probably due to governmental public efforts through the establishment of policies, such as Brasil Sorridente (“Smiling Brazil"), in 2004,30.

This research improves the knowledge about the need for dental treatment in secondary care, since it points out that access to primary care is a contextual/municipal protective factor. The role of increased access to PHC services as one of the factors responsible for improving the oral health of Brazilians has been proven, despite its persistent inequitable access ${ }^{31}$. Effective oral health care services can also influence the achievement of SDC goals, as the more needs are resolved in primary care, the lower the number of referrals are needed to specialised care ${ }^{32}$. In addition, the higher resolution of dental needs in the PHC ensures an adequate supply of services, avoiding the overload of specialised care ${ }^{33}$. This fact is important so that each need is actually met within its level of complexity, improving the interactions between the levels of care. Furthermore, it assumes that with correct access to oral health ser- vices in PHC, one would expect to see decreased dental care needs in secondary care. High dental treatment needs increase the number of consultations required for each individual, resulting in a lower access to individual dental treatment. These findings give evidence to the great influence that the need for treatment has on the access to basic oral health services ${ }^{34}$. Despite the great effort of NOHP in increasing access to SDC, there are many municipalities that did not offer this level of care $^{35}$.

Again, in regards to the need for treatment, a Canadian study using data from a national survey found that individuals who visited a dentist more than once a year, visited the dentist less than once a year, visited a dentist for emergencies only or never had a dental consultation tended to show a greater need for dental treatment ${ }^{5}$. This result is likely to extend into secondary care due to the accumulation of these needs over time, generating a demand for more complex treatment.

It is necessary to point out that the cross-sectional nature of this study does not allow the researches to establish cause and effect relationships, but only associations. Despite the potential to generate evidence of a contextual effect on the outcome researched, the use of aggregated data is a limiting factor as it was not collected for research purposes. Moreover, the inferences of this survey are limited to one Brazilian state. Despite these limitations, this study enhances scientific knowledge because we were able to identify the influence of contextual variables on oral health needs, using a multilevel analysis. On the other hand, considering that we evaluated a homebased survey, the proportion of women was higher than in the state of Minas Gerais.

In view of the above, we conclude that low income (at the individual level) and lack of access to oral health primary care (at contextual level) were associated with specialised dental treatment needs/secondary care in Minas Gerais, Brazil. Thus, the identification of factors influencing the dental treatment needs of the population in secondary care is the first step towards developing and planning public health programs. 


\section{Collaborations}

MB Azevedo, RS Pinto, MHNG Abreu and SD Lucas worked on the design, final writing, and methodological research. SD Lucas submitted the article to this journal.

\section{References}

1. Instituto Brasileiro de Geografia e Estatística (IBGE). Acesso e utilização de serviços de saúde 1998. Pesquisa Nacional por Amostra de Domicílios [Internet]. Rio de Janeiro: IBGE; 2000. [acessado 2018 Out 18]. Disponível em: https://ww2.ibge.gov.br/home/estatistica/ populacao/trabalhoerendimento/pnad98/saude/saude.pdf

2. Pucca Junior GA, Costa JFR, Chagas LD, Sivestre RD. Oral health policies in Brazil. Braz Oral Res 2009; 23(1):9-16.

3. Pucca Junior GA, Lucena EHG, Cawahisa PT. Financing national policy on oral health in Brazil in the context of the Unified Health System. Braz Oral Res 2010; 24(1):26-32.

4. Brasil. Ministério da Saúde (MS).Diretrizes da política nacional de saúde bucal [Internet]. Brasília: MS; 2004 [acessado 2018 Ago 18]. Disponível em: http://bvsms. saude.gov.br/bvs/publicacoes/politica_nacional_brasil_sorridente.htm

5. Ramraj C, Azarpazhooh A, Dempster L, Ravaghi V, Quiñonez C. Dental treatment needs in the Canadian population: analysis of a nationwide cross-sectional survey. BMC Oral Health 2012; 12:46.

6. Roncalli AG, Tsakos G, Sheiham A, Souza GC, Watt RG. Social determinants of dental treatment needs in Brazilian adults. BMC Public Health 2014; 14:1097.

7. Pinto RS, Roncalli AG, Abreu MHNG, Vargas AMD. Use of public oral health services by the adult population: a multilevel analysis. PLoS One 2016; 11(1):e0145149.

8. Minas Gerais. Secretaria de Estado de Saúde de Minas Gerais. Subsecretaria de Políticas e Ações de Saúde Superintendência de Redes de Atenção à Saúde. Diretoria de Saúde Bucal. SB Minas Gerais: pesquisa das condições de saúde bucal da população mineira: resultados principais. Belo Horizonte: Autêntica; 2013.

9. Costa SM, Vasconcelos M, Haddad JPA, Abreu MHNG. The severity of dental caries in adults aged 35 to 44 years residing in the metropolitan area of a large city in Brazil: a cross-sectional study. BMC Oral Health 2012; 12:25.

10. Newton JT, Bower E. The social determinants of oral health: new approaches to conceptualizing and researching complex causal networks. Community Dent Oral Epidemiol 2005; 33(1):25-34.

11. Watt RG. Social determinants of oral health inequalities: implications for action. Community Dent Oral Epidemiol 2012; 40(2):44-48.

12. Petersen PE, Kwan S. Equity, social determinants and public health programmes - the case of oral health. Community Dent Oral Epidemiol 2011;39(6):481-487.

13. Lee HY, Choi YH, Park HW, Lee SG. Changing patterns in the association between regional socio-economic context and dental caries experience according to gender and age: a multilevel study in Korean adults. Int J Health Geogr 2012; 11:30.

14. Boing AF, Bastos JL, Peres KG, Antunes JL, Peres MA. Social determinants of health and dental caries in Brazil: a systematic review of the literature between 1999 and 2010. Rev Bras Epidemiol 2014; 17(2):102115. 
15. Antunes JL, Peres MA, Mello TRC, Waldman EA. Multilevel assessment of determinants of dental caries experience in Brazil. Community Dent Oral Epidemiol 2006; 34(2):146-152.

16. Bastos JL, Boing AF, Peres KG, Antunes JLF, Peres MA. Periodontal outcomes and social, racial and gender inequalities in Brazil: a systematic review of the literature between 1999 and 2008. Cad Saude Publica 2011; 27(2):s141-s153.

17. Instituto Brasileiro de Geografia e Estatística (IBGE). Contas regionais do Brasil 2010 [Internet]. Rio de Janeiro: IBGE; 2012. [acessado 2018 Ago 19]. Disponível em: https://biblioteca.ibge.gov.br/visualizacao/ livros/liv62688.pdf

18. Brasil. Ministério da Saúde (MS). SB Brasil 2010: Pesquisa nacional de saúde bucal: resultados principais [Internet]. Brasília: MS; 2012. [acessado 2018 Ago 18]. Disponível em: http://bvsms.saude.gov.br/bvs/ publicacoes/pesquisa_nacional_saude_bucal.pdf

19. Brasil. Portaria no 2.488 , de 21 de outubro de 2011. Aprova a política nacional de atenção básica, estabelecendo a revisão de diretrizes e normas para a organização da atenção básica, para a Estratégia Saúde da Família (ESF) e o Programa de Agentes Comunitários de Saúde (PACS). Diário Oficial da União; 2011.

20. Snijders TAB, Bosker RJ. Multilevel analyses: an introduction to basic and advanced multilevel modelling. $2^{\text {nd }}$ ed. London: Sage Publications; 2012.

21. Szwarcwald CL, Souza-Júnior PRB, Damacena GN. Socioeconomic inequalities in the use of outpatient services in Brazil according to health care need: evidence from the World Health Survey. BMC Health Serv Res 2010; 10:217.

22. Reda SF, Reda SM, Thomson WM, Schwendicke F. Inequality in utilization of dental services: a systematic review and meta-analysis. Am J Public Health 2018; 108(2):e1-e7.

23. Pinto RS, Abreu MHNG, Vargas AMD. Comparing adult users of public and private dental services in the state of Minas Gerais, Brazil. BMC Oral Health 2014; 14:100.

24. Telford C, Murray L, Donaldson M, O’Neil C. An analysis examining socio-economic variations in the provision of NHS general dental practitioner care under a fee for service contract among adolescents: Northern Ireland Longitudinal Study. Community Dent Oral Epidemiol 2012; 40(1):70-79.

25. Trohel G, Bertaud-Gounot V, Soler M, Chauvin P, Grimaud O. Socio-economic determinants of the need for dental care in adults. PLoS One 2016; 11(7):e0158842.

26. Costa SM, Martins CC, Bonfim MLC, Zina LG, Paiva SM, Pordeus IA, Abreu MHNG. A systematic review of socioeconomic indicators and dental caries in adults. Int J Environ Res Public Health 2012; 9(10):3540-3574.
27. Schuch HS, Peres KG, Singh A, Peres MA, Do LG. Socioeconomic position during life and periodontitis in adulthood: a systematic review. Community Dent Oral Epidemiol 2017; 45(3):201-208.

28. Seerig LM, Nascimento GG, Peres MA, Horta BL, Demarco FF. Tooth loss in adults and income: Systematic review and meta-analysis. J Dent 2015; 43(9):10511059.

29. Chaves SCL, Soares FF, Rossi TRA, Cangussu MCT, Figueiredo ACL, Cruz DN, Cury PR. Characteristics of the access and utilization of public dental services in medium-sized cities. Cien Saude Colet 2012; 17(11):3115-3124.

30. Celeste RK, Nadanovsky P, Fritzell J. Trends in socioeconomic disparities in the utilization of dental care in Brazil and Sweden. Scand J Public Health 2011; 39:(6):640-648.

31. Soares FF, Chaves SCL, Cangussu MCT. Desigualdade na utilização de serviços de saúde bucal na atenção básica e fatores associados em dois municípios brasileiros. Rev Panam Salud Publica 2013; 34(6):401-406.

32. Santana DA, Santos LPS, Carvalho FS, Carvalho CAP. Desempenho dos centros de especialidades odontológicas de uma região de saúde da Bahia. Cad Saude Colet 2015; 23(3):261-267.

33. Laroque MB, Fassa AG, Castilhos ED. Evaluation of secondary dental health care at the dental specialties center, Pelotas, Rio Grande do Sul, Brazil, 2012-2013. Epidemiol Serv Saude 2015; 24(3):421-430.

34. Esteves RSS, Mambrini JVM, Oliveira ACB. Performance of primary dental care services: an ecological study in a large Brazilian city. Scientific World J 2013; 2013:176589.

35. Lino PA, Werneck MA, Lucas SD, Abreu MHNG. Analysis of secondary care in oral health in the state of Minas Gerais, Brazil. Cien Saude Colet 2014; 19(9):3879-3888.

Article submitted 08/04/2018

Approved 03/12/2018

Final version submitted 05/12/2018 